\title{
SURVEY HIPERTENSI DAN PENCEGAHAN KOMPLIKASINYA DI WILAYAH PESISIR KECAMATAN PERCUT SEI TUAN TAHUN 2018
}

\author{
Zuhrina Aidha ${ }^{1}$, Azhari Akmal Tarigan ${ }^{2}$ \\ Fakultas Kesehatan Masyarakat UINSU Medan \\ Email: zuhrinaaidha@uinsu.ac.id ${ }^{1}$ \\ azhariakmaltarigan@uinsu.ac.id ${ }^{2}$
}

\begin{abstract}
Non-communicable diseases, such as hypertension, pose a threat to people in developing countries. Hypertension is the cause of death, called the silent killer. This disease is a challenge to health problems globally because of its high prevalence causing cardiovascular disease and chronic kidney disease (Mills et al., 2016). The prevalence of hypertension in North Sumatra reaches $6.7 \%$ of the population in North Sumatra, based on data from the Ministry of Health's Health Research and Development Agency. This means that the population of North Sumatra suffering from hypertension reaches 12.42 million people spread across several districts (Ministry of Health, 2013). Karo Regency is one of the highest numbers of hypertension, following Deli Serdang district. In 2016 the number of hypertensive patients in Karo Regency was 12,608 people, this prevalence was higher in female sex (52\%) men (48\%), the largest in the age group 55-59 years (Simbolon, 2016). Method: Type of research is explorative using the quantitative method with a quasi experiment approach. Measurements were made before and after intervention. Determination of the number of samples by simple random sampling, and obtained a sample of 30 people. Data analysis used univariate analysis, and t-dependent analysis to find out before and after training. The results of this study, that the prevalence of hypertension before and after antistroke exercise intervention has decreased. Where before the intervention was given the blood pressure of respondents above 180/100 $m m H g$, but after being given an intervention the average blood pressure of the respondents was in the figure of 140/85 $\mathrm{mmHg}$. Subjective complaints felt by respondents before and after being given an anti-stroke exercise intervention experienced a change. Initially the complaint was at the level of weight and medium, after being intervened the complaint was at a moderate and mild level.
\end{abstract}

Keywords: hypertension, gymnastics, antistroke, elderly, complaint

\section{PENDAHULUAN}

Penyakit tidak menular, seperti hipertensi menjadi ancaman bagi masyarakat di negara berkembang. Penyakit hipertensi menjadi penyebab kematian, disebut silent killer. Penyakit ini menjadi tantangan masalah kesehatan secara global karena prevalensinya yang tinggi menyebabkan penyakit kardiovaskuler dan penyakit ginjal kronik (Mills et al., 2016). World Health Organization (WHO) merilis, hipertensi sering kali menjadi penyebab kematian yang tidak terdiagnosa. Penderita hipertensi yang tidak terdiagnosa, tidak mendapat perawatan sehingga tidak 
dapat mengontrol tekanan darah dalam jangka panjang mengakibatkan terjadi komplikasi hipertensi, peningkatan penyakit kardiovaskuler (WHO, 2013).

Sebuah hasil penelitian menyebutkan Usia pasien hipertensi masuk dalam kelompok usia lansia akhir sebanyak 16 responden $(30,2 \%)$. Jenis kelamin pasien sebagian besar adalah perempuan sebanyak 30 responden $(56,6 \%)$. pasien tidak patuh minum obat sebanyak 43 responden $(81,1 \%)$. pasien tidak obesitas sebanyak 32 responden $(60,4 \%)$. Sebagian besar pasien tidak memiliki keluarga dengan riwayat hipertensi sebanyak 29 responden $(54,7 \%)$. pasien tidak memiliki kebiasan merokok sebanyak 32 responden $(60,4 \%)$. Kebiasaan olah raga sebagian besar pasien adalah tidak teratur sebanyak 34 responden (64,2\%). Tekanan darah pada pasien hipertensi masuk dalam kategori hipertensi tahap I sebanyak 28 responden (52,8\%) (Azhar, 2017).

Prevalensi hipertensi di Propinsi Sumatera Utara mencapai 6.7\% dari jumlah penduduk di Sumatera Utara, berdasarkan data Badan Litbangkes Kementerian Kesehatan. Ini berarti bahwa jumlah penduduk Sumatera Utara yang menderita hipertensi mencapai 12,42 juta jiwa tersebar di beberapa Kabupaten (Kemenkes, 2013). Kabupaten Karo salah satu jumlah hipertensi yang terbanyak, menyusul kabupaten Deli Serdang. Tahun 2016 jumlah penderita hipertensi di Kabupaten Karo sebesar 12.608 orang, prevalensi ini lebih tinggi pada jenis kelamin perempuan (52\%) lelaki (48\%), terbesar pada kelompok umur 55 - 59 tahun (Simbolon, 2016). Menurut Azhar (2017) dalam hasil penelitiannya menyebutkan karakteristik pasien hipertensi di Puskesmas Gamping I Sleman DIY adalah masuk dalam kelompok usia lansia akhir, berjenis kelamin perempuan, tidak patuh minum obat, tidak mengalami obesitas, tidak memiliki keluarga dengan riwayat hipertensi, tidak memiliki kebiasan merokok, kebiasan olah raga tidak teratur, dan memiliki tekanan darah masuk dalam kategori hipertensi tahap I.

Data dari Dinas Kesehatan Provinsi Sumatera Utara, tercatat 50.162 orang menderita Hipertensi. Data tersebut, tercatat paling banyak menderita Hipertensi adalah wanita dengan jumlah 27.021. Usia yang paling banyak menderita adalah usia di atas 55 tahun dengan jumlah 22.618 kemudian usia 18 sampai 44 tahun 
dengan jumlah 14.984 dan usia 45 sampai 55 tahun dengan jumlah 12.560 . Tahun 2015, tercatat penderita Hipertensi di Sumut pada JanuariOktober 2015, mencapai15.1939. Penderita terbanyak adalah wanita dengan jumlah 87774. Usia penderita paling banyak terlihat pada data itu juga usia di atas 55 tahun dengan jumlah 85254, disusul usia 45 sampai 55 tahun dengan jumlah 44909 dan usia 18 sampai 44 tahun dengan jumlah 21776 (Sumut Pos, 2016).

Hipertensi merupakan penyebab kematian utama yang memicu berbagai komplikasi diantaranya stroke, kematian jaringan otot jantung dan kegagalan fungsi ginjal. Faktor pemicu hipertensi dapat dibedakan atas yang tidak dapat terkontrol (seperti keturunan, jenis kelamin, dan umur) dan yang dapat dikontrol (seperti kegemukan, kurang olahraga, merokok, serta konsumsi alkohol dan garam), (Sigarlaki, 2006). Hipertensi memiliki berbagai faktor resiko yang memiliki keterkaitan erat dengan pemicu terjadinya penyakit tersebut. Berbagai faktor resiko hipertensi meliputi genetik, ras, usia, jenis kelamin, merokok, obesitas, serta stress psikologis dan faktor yang menyebabkan kambuhnya hipertensi antara lain pola makan, merokok dan stres (Yogiantoro, 2006 \& Marliani, 2007). Faktor resiko hipertensi di Indonesia adalah umur, pendidikan rendah, kebiasaan merokok, menkonsumsi minuman berkafein $>1$ kali per hari, konsumsi alkohol, kurang aktifitas fisik, obesitas dan obesitas abdominal (Rahajeng, 2009).

Masyarakat di Indonesa sendiri kesadaran dan pengetahuan tentang penyakit hipertensi masih sangat rendah, sehingga dukungan keluarga terhadap anggota keluarga penderita hipertensi juga rendah. Hal ini terbukti masyarakat lebih memilih makanan siap saji yang umumnya rendah serat, tinggi lemak, tinggi gula dan mengandung banyak garam. Pola makan yang kurang sehat ini merupakan pemicu penyakit hipertensi (Dinkes, 2008).

Beberapa faktor yang dapat menyebabkan komplikasi pada penderita hipertensi diantaranya adalah tingkat pengetahuan dan sikap keluarga terhadap pencegahan komplikasi hipertensi. Hal ini sejalan dengan penelitian yang dilakukan oleh Nugraha (2013) yang menyebutkan bahwa ada hubungan antara pengetahuan dan sikap keluarga terhadap pencegahan 
komplikasi hipertensi di Puskesmas Sangkrah Surakarta (p-value) 0,000.

Survey awal di wilayah pesisir Kecamatan Percut Sei Tuan Kabupaten Deli Serdang, bulan Nopember 2017 pada 30 responden wanita, diperoleh data $60 \%$ menderita hipertensi, konsumsi makanan tinggi garam dan tidak ada aktivitas olah raga yang rutin dilakukan. Berdasarkan data tersebut, perlu dilakukan penelitian untuk mendapatkan data prevalensi hipertensi, dan upaya mencegah komplikasi hipertensi yang dapat mengancam penderita hipertensi setiap saat sehingga deteksi dini hipertensi dapat mencegah komplikasi penyakit lainnya.

Penelitian Herwati (2011) menyatakan lebih dari separuh $(56.4 \%)$ penderita hipertensi melakukan pola diet yang kurangbaik. Sebagian besar $(80,8$ $\%$ penderita hipertensi memiliki kebiasaan berolahraga tidak baik. Sebagian besar $(82.1 \%)$ penderita hipertensi tekanan darahnya tidak terkontrol.Terdapat hubungan yang bermakna antara pola diet dengan terkontrolnya tekanan darah pada penderita hipertensi.Terdapat hubungan yang bermakna antara kebiasaan berolahraga dengan terkontrolnya tekanan darah pada penderita hipertensi.
Berdasarkan hasil survey awal di atas peneliti tergerak untuk meneliti upaya yang dilakukan masyarakat wilayah pesisir kecamatan Percut Sei Tuan Kabupaten Deli Serdang. Selain itu penelitian ini selaras dengan visi prodi IKM FKM UINSU Medan yaitu unggul dalam mewujudkan masyarakat pembelajar berdasarkan nilai-nilai islam dalam bidang kesehatan masyarakat di wilayah pesisir tahun 2028, dan salah satu misi adalah melaksanakan pendidikan, pengajaran, penelitian dan pengabdian masyarakat secara professional dalam bidang ilmu kesehatan masyarakat yang berdasarkan nilai-nilai islam. Penelitian ini juga nantinya digunakan sebagai alat untuk mempromosikan keberadaan prodi IKM FKM UINSU Medan.

\section{Jenis dan Cara Pengumpulan Data}

Jenis penelitian ini adalah eksploratif, penelitian yang memiliki tujuan untuk mendapatkan keterangan, wawasan, pengetahuan, ide, gagasan dan pemahaman. Penelitian eksplorasi dimaksudkan untuk mencari ide atau hubungan yang baru, bertitik tolak pada variabel (Noor, 2013). Rancangan penelitian ini menggunakan quasi eksperiment (eksperimen semu) one group time resies design (satu grup 
desain runtut waktu). Rancangan ini digunakan karena penelitian ini memberikan perlakuan dalam bentuk intervensi (pencegahan komplikasi hipertensi). Pengukuran pada subyek penelitian dilakukan 2 kali, satu kali pengukuran awal (pre test) pada subjek yang diteliti sebelum ada perlakuan (treatment), selanjutnya pengukuran satu kali setelah perlakuan (post test).

Penelitian dilaksanakan selama 6 bulan pada Mei 2018 - Oktober 2018. Kegiatan penelitian dimulai sejak mengurus ijin penelitian, survey awal, persetujuan proposal oleh lembaga peneliti, pengukuran pre intervensi, pelaksanaan intervensi, analisis data hingga menyusun laporan penelitian. Teknik pengambilan sampel diambil menggunakan simple random sampling, jumlah sampel sebanyak 30 orang.

\section{Analisis Data}

Analisis data dilakukan dengan cara, Analisis univariat tabulasi data dalam bentuk tabel distribusi frekwensi, dilanjutkan dengan analisis bivariat uji $\mathrm{t}$ paired menggunakan software SPSS versi 19 (Hastono, 2016). Uji normalitas data, untuk menganalisis data terdistribusi secara normal, sebagai syarat uji parametrik ( $t$ dependen) (Riyanto, 2010).

\section{Hasil Penelitian}

\section{Karakteristik Responden Berdasarkan Tingkat Pendidikan}

Pendidikan memiliki peran penting dalam kehidupan masyarakat sebab tingkat pendidikan menjadi satu ukuran maju tidaknya masyarakat tersebut sehingga semakin tinggi tingkat pendidikan suatu masyarakat maka akan semakin berkembanglah peradaban sampai pada perkembangan taraf kehidupan dan gaya hidup. Selain itu pendidikan juga memiliki peran penting dalam proses pemberdayaan sumber daya manusia (SDM) yang handal, sebab dengan SDM yang handal maka proses pembangunan pun akan lebih bisa berjalan baik dan lancar. Secara umum dapat dikatakan bahwa masyarakat Kecamatan Percut Sei Tuan termasuk masyarakat yang sudah maju dalam bidang pendidikan, hal ini dibuktikan dengan rata-rata anggota masyarakatnya telah menempuh pendidikan formal berbagai tingkat pendidikan, baik itu pendidikan pada tingkat dasar, menengah pertama, menengah atas, bahkan juga telah sampai pada pendidikan tinggi baik pada jenjang sarjana starata satu (S1) dan banyak masyarakatnya sudah mulai minat untuk melanjutkan pendidikan hingga Pasca Sarjana (S2), hal ini ditandai jenjang 
pendidikan dengan fasilitas Tk sampai perguruan tinggi.

Sebanyak 30 responden yang di teliti, 50\% (30) responden perpendidikan terakhir pada tingkat Sekolah Menengah Atas (SMA) dan Perguruan Tinggi (PT), sisanya adalah responden dengan pendidikan terakhir pada tingkat Sekolah Dasar (SD) dan Sekolah Menengan Pertama (SMP).

\section{Karakteristik Berdasarkan Pekerjaan (Mata Pencaharian)}

Masyarakat dan ekonomi adalah ibarat dua sisi mata uang yang tak dapat dipisahkan artinya masyarakat dan ekonomi adalah akan selalu berkaitan, hal ini karena kemakmuran atau maju mundurnya suatu masyarakat dapat diukur salah satunya dari segi taraf perekonomiannya dan masyarakat adalah kaum pelaku ekonomi artinya perekonomian tidak akan ada bila masyarakatnya tidak ada. Tingkat perekonomian masyarakat banyak ditentukan dari segi usaha atau mata pencahariannya, semakin maju suatu usaha maka akan semakin makmur pulalah para pelaku usaha tersebut.

Informasi yang didapatkan dari responden yang diteliti, sebanyak 20 $(66,7 \%)$ responden memilih opsi "Lainnya" pada kuesioner yang ini menunjukkan mereka adalah ibu rumah tangga. Setelah dilakukan wawancara lebih lanjut didapatkan informasi dari 20 responden tersebut bahwa suami mereka bermatapencaharian sebagai nelayan. Sisanya, sebanyak $15(16,6 \%)$ responden bermatapencaharian sebagai Pegawai Swasta, sebanyak $13,3 \%$ (4) orang responden bermata pencaharian berwiraswasta, dan $1(3,3 \%)$ orang responden merupakan seorang pensiunan.

\section{Karakteristik Berdasarkan Usia}

Responden

Menurut kelompok usia penduduk Desa Percut kelompok usia di atas 30 tahun lebih mendominasi yaitu sebanyak 1.374 orang sedangkan usia 20-30 sebanyak 808 orang, dan sisanya merupakan kelompok usia di bawah 20 tahun. Penelitian ini mengelompokkan usia menjadi kelompok usia $<50$ tahun, 50-60 tahun, dan >60 tahun. Alasan dilakukan pengelompokkan pada usia tersebut adalah karena penelitian ini dilakukan pada usia lanjut atau di atas 50 tahun. Informasi yang didapatkan pada penelitian, sebanyak 9 orang $(30 \%)$ responden berada pada kelompok usia 50-60 tahun, 5 orang $(16,7 \%)$ responden berada usia $>60$ tahun, dan 16 orang $(53,3 \%)$ responden berusia $<50$ tahun, dan setelah dilakukan wawancara 
selanjutnya berada pada usia 47-49 tahun.

\section{Distribusi Frekuensi Tekanan Darah}

Tekanan darah adalah tekanan yang dihasilkan oleh pompa jantung untuk menggerakkan darah keseluruh tubuh. Darah membawa nutrisi dan oksigen ke seluruh bagian tubuh. Tekanan darah tinggi, atau hipertensi, mengacu pada kondisi dimana darah dipompa keseluruh tubuh pada tekanan tinggi.

Pengukuran tekanan darah pada penelitian ini dilakukan pada dua tahap yaitu Pretest (pengukuran sebelum intervensi) dan Posttest (pengukuran setelah intervensi). Terdapat perbedaan yang dignifikan terhadap perubahan tekanan darah sebelum dan sesudah intervensi. Secara rinci dapat dilihat pada tabel di bawah ini.

Tabel 1 Hasil Pengukuran Tekanan Darah Pre tes

\begin{tabular}{ccc}
\hline Kategori & $\begin{array}{c}\text { Frekwensi } \\
(\mathbf{f})\end{array}$ & $\begin{array}{c}\text { Persentase } \\
(\boldsymbol{\%})\end{array}$ \\
\hline Rendah & 5 & 16,7 \\
Normal & 9 & 30 \\
Tinggi & 16 & 53,5 \\
\hline Jumlah & 30 & 100 \\
\hline
\end{tabular}

Tabel 2 Hasil Pengukuran Tekanan Darah Pos Tes

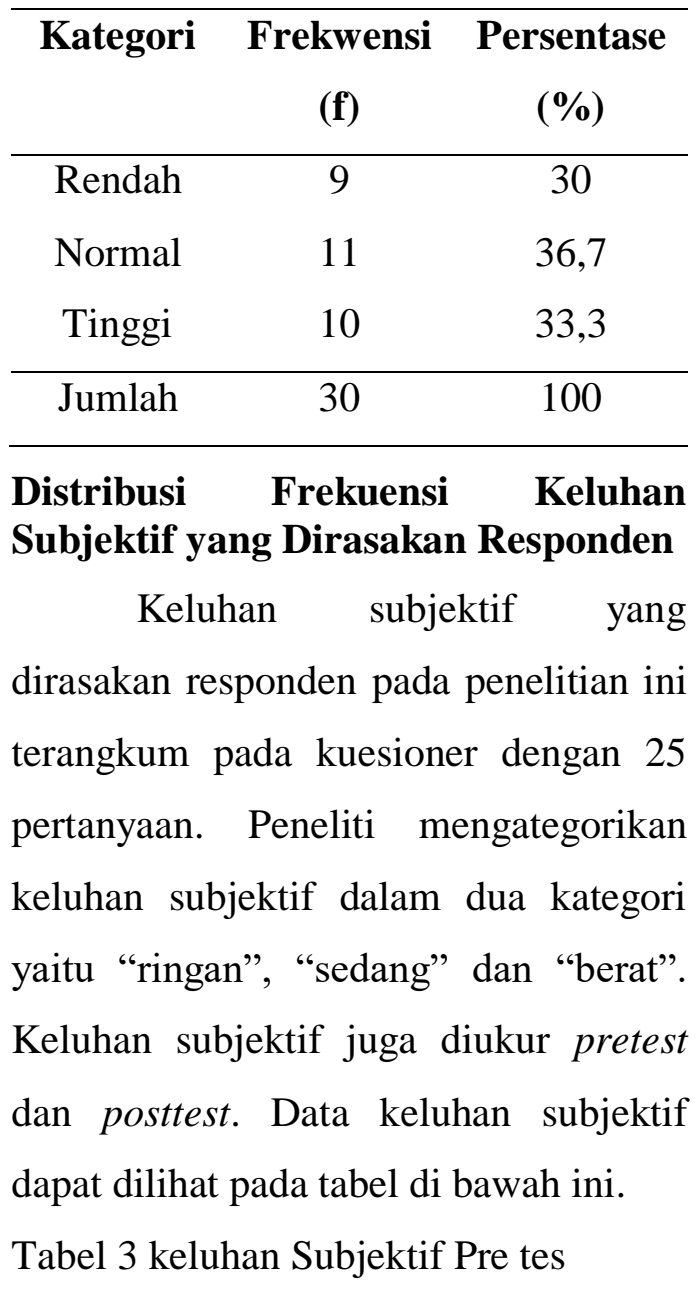

\begin{tabular}{|c|c|c|}
\hline Keluhan & $\begin{array}{l}\text { Frekwensi } \\
\text { (f) }\end{array}$ & $\begin{array}{c}\text { Persentase } \\
(\%)\end{array}$ \\
\hline Ringan & 1 & 3,3 \\
\hline Sedang & 21 & 70 \\
\hline Berat & 8 & 26,7 \\
\hline Jumlah & 30 & 100 \\
\hline \multicolumn{3}{|c|}{ Tabel 4 Keluhan Subjektif Pos Tes } \\
\hline Keluhan & $\begin{array}{l}\text { Frekwensi } \\
\text { (f) }\end{array}$ & $\begin{array}{c}\text { Persentase } \\
(\%)\end{array}$ \\
\hline Ringan & 8 & 26,7 \\
\hline Sedang & 22 & 73,3 \\
\hline Jumlah & 30 & 100 \\
\hline
\end{tabular}


Wilayah pesisir merupakan daerah peralihan laut dan daratan. Kondisi tersebut menyebabkan wilayah pesisir mendapatkan tekanan dari berbagai aktivitas dan fenomena yang terjadi di darat maupun di laut. Fenomena yang terjadi di daratan antara lain abrasi, banjir dan aktivitas yang dilakukan oleh masyarakat yaitu pembangunan permukiman, pembabatan hutan untuk persawahan, pembangunan tambak dan sebagai yang pada akhirnya memberi dampak pada ekosistem pantai. Demikian pula fenomena-fenomena di lautan seperti pasang surut air laut, gelombang badai dan sebagainya (Hastuti, 2012).

Selain masalah lingkungan masalah kesehatan juga banyak terjadi di daerah pesisir. Penyakit yang paling sering terjadi adalah penyakit kulit, diare dan hipertensi. Berdasarkan Riskesdas Nasional tahun 2007, hipertensi berada di urutan ketiga penyebab kematian semua umur, setelah stroke dan TB, dengan proporsi kematian sebesar $6,8 \%$. Adapun prevalensi nasional hipertensi pada penduduk umur $>18$ tahun adalah sebesar $31,7 \%$. Dengan prevalensi hipertensi tertinggi di Kepulauan Natuna (wilayah pantai) sebanyak 53,3\% sedangkan prevalensi terendah di
Pegunungan Jayawijaya sebanyak 6,8\%. Hal ini antara lain berhubungan dengan adanya pola makan terutama intake natrium yang mendukung risiko terjadinya hipertensi (Riskesdas, 2007).

Hasil penelitian Rusliafa menunjukan bahwa hipertensi lebih banyak pada wilayah pesisir dibandingkan dengan wilayah pegunungan. Dimana masing-masing variabel saling mempengaruhi. Natrium atau sodium adalah sebuah mineral yang ditemukan dalam tubuh dan dalam banyak makanan. Natrium atau sodium adalah sebuah mineral yang ditemukan dalam tubuh dan dalam banyak makanan. Natrium merupakan nutrisi penting untuk mempertahankan mempertahankan volume darah, mengatur keseimbangan air dalam sel, dan menjaga fungsi saraf. Ginjal mengontrol keseimbangan natrium dengan meningkatkan atau menurunkan natrium dalam urin.

Menurut Menkes, risiko kesehatan selalu mengikuti setiap gerak nelayan dalam upaya memenuhi kebutuhan hidupnya. Mengutip data hasil penelitian Kementerian Kesehatan (2006) mengenai penyakit dan kecelakaan yang terjadi pada nelayan dan penyelam tradisional, menyebutkan 
bahwa sejumlah nelayan di Pulau Bungin, Nusa Tenggara Barat menderita nyeri persendian $(57,5 \%)$ dan gangguan pendengaran ringan sampai ketulian $(11,3 \%)$. Sedangkan, nelayan di Kepulauan Seribu, DKI Jakarta, mengalami kasus barotrauma $(41,37 \%)$ dan kelainan dekompresi $(6,91 \%)$.

Berdasarkan hasil penelitian sebahagian responden memiliki pendidikan akhir setara sekolah dasar dan sekolah menengah pertama. Pendidikan merupakan salah satu faktor yang mempengaruhi perilaku seseorang. Termasuk perilaku mencegah penyakit dan meningkatkan derajat kesehatan masyarakat. Menurut teori Lawrence Green dalam buku pengantar ilmu kesehatan masyarakat karya Cecep Triwibowo (2015) bahwa perubahan perilaku seseorang ditentukan oleh tiga faktor yaitu (1) faktor predisposisi, (2) faktor pendukung, dan (3) faktor pendorong.

Usia merupakan faktor risiko penyebab hipertensi yang tidak dapat diubah. Oleh karena itu seiring bertambahnya usia maka prevalensi kejadian hipertensi meningkat. Hal ini juga disebabkan karena dengan bertambahnya usia maka menurun juga fungsi-fungsi tubuh terutama elastisitas pembuluh darah dan kinerja jantung. Mengingat kembali pengertian penyakit degeneratif adalah penyakit yang terjadi karena menurunnya fungsi tubuh. Dan hipertensi merupakan salah satu jenis penyakit degeneratif.

Penelitian ini membagi dalam tiga kategori usia lanjut yaitu < 50 tahun, 50-60 tahun, dan >60 tahun. Didapatkan prevalensi hipertensi dari masingmasing kategori usia adalah 16, 5, dan 9 orang. Artinya, prevalensi hipertensi tinggi pada usia lanjut. Sejalan dengan hasil penelitian yang dilakukan oleh Dedullah, bahwa responden dengan kategori umur $\geq 43$ tahun mengalami hipertensi sebanyak $50 \quad(33,3 \%)$ dibandingan dengan kelompok usia $\leq 43$ tahun pada masyarakat Kelurahan Montoboi Kecil. Kategori umur $\geq 43$ tahun memiliki resiko 5,263 kali lebih besar menderita hipertensi dibandingkan dengan kategori umur $\leq 43$ tahun. Dengan kelompok umur yang sama, penelitian Raihan juga mendapatkan hasil yang signifikan terhadap hubungan antara umur dan prevalensi hipertensi.

Penelitian yang dilakukan Gerungan, A dkk (2016) bahwa diperoleh hasil ada hubungan yang bermakna antara umur dengan kejadian hipertensi, umur $\geq 40$ tahun memiliki 
risiko terkena hipertensi sebesar 11,71 kali dibandingkan dengan umur $<40$ Tahun. Selain itu penelitian diwilayah Thailand menunjukan adanya hubungan antara usia dengan hipertensi dan orang dengan usia $>40$ tahun berisiko 4,2 kali mengalami hipertensi dibandingkan dengan yang berusia kurang dari 40 tahun. Hak ini terjadi karena semakin bertambahnya usia elastisitas pembuluh darah akan mengecil menyebabkan aliran darah ke tubuh semakin sedikit sehingga jantung harus bekerja keras untuk memenuhi aliran darah sehingga berdampak pada hipertensi (Journal Medicine, 2015) (Ratna Ningsih).

Penelitian yang dilakukan Jamalia menunjukkan hal yang sama dengan hasil penelitian ini. Penelitian yang dilakukan terhadap penderita hipertensi di Desa Jatirunggo Semarang ini menunjukkan hasil yang signifikan antara pemberian intervensi senam anti stroke dengan penurunan tekanan darah responden. Sebelum dilakukan intervensi tekanan darah tertinggi 160/140 mmHg, setelah dilakukan intervensi mengalami penurunan yaitu tekanan darah tertinggi setelah intervensi 100/90 mmHg. Penurunan tekanan darah sistolik dapat dijelaskan dari dua mekanisme yaitu terjadinya perubahan pada aktivitas sistem saraf simpatik dan respon vaskular setelah berolahrga.

Menurut Stanley dalam Jamalia, Senam anti stroke dapat meningkatkan jumlah darah yang dipompa setiap menitnya oleh jantung khususnya dari ventrikel kiri. Melalui peningkatan jumlah darah yang dipompa akan mengakibatkan jumlah oksigen yang beredar ke seluruh tubuh juga meningkat. Senam anti stroke juga meningkatkan kebutuhan energi oleh sel, jaringan dan organ tubuh, sehingga meningkatkan aktivitas pernafasan dan dapat meningkatkan aliran balik vena yang menyebabkan peningkatan volume sekuncup yang akan langsung meningkatkan curah jantung. Fase ini mampu menurunkan aktivitas pernafasan otot rangka dan menyebabkan aktivitas saraf simpatis meningkat. Setelah itu kecepatan jantung menurun, volume sekuncup menurun, dan terjadi vasodilatasi arteriol vena. Penurunan ini mengakibatkan penurunan curah jantung dan penurunan resistensi perifer total, sehingga terjadi penurunan tekanan darah (Sherwood, 2005).

Penelitian lain juga mengungkapkan efektifitas kombinasi terapi kukusan labu siam dan senam anti 
stroke terhadap penurunan tekanan darah. Penelitian yang dilakukan oleh Tul'aini menyebutkan terjadi penurunan tekanan darah responden yang diberikan terapi kombinasi rebusan labu siam dan senam antistroke. Hal sejalan juga diungkapkan dalam penelitian Maulana bahwa terjadi penurunan tekanan darah responden yang diberikan perlakuan senam hipertensi.

\section{KESIMPULAN}

1. Prevalensi hipertensi sebelum dan setelah dilakukan intervensi senam antistroke mengalami penurunan. Dimana sebelum diberikan intervensi tekanan darah responden di atas 180/100 mmHg, namun setelah diberi intervensi rata-rata tekanan darah responden berada pada angka 140/85 $\mathrm{mmHg}$.

2. Keluhan subjektif yang dirasakan responden sebelun dan setelah diberikan intervensi senam anti stroke mengalami perubahan. Semula keluhan berada pada tingkat berat dan sedang, seteleh diintervensi keluhan berada pada tingkat sedang dan ringan.

3. Penerapan senam antistroke efektif dilakukan pada responden dengan tekanan darah tinggi untuk menormalkan tekanan darah, ditambah dengan konsumsi makanan seombang.

\section{Saran}

1. Bagi responden, senam antistroke baik dilakukan sehari-hari diselasela kegiatan.

2. Bagi peneliti, disarankan melakukan penelitian lanjutan terkait efektifitas senam antistroke.

\section{DAFTAR PUSTAKA}

Azhar, isroul. 2017. Gambaran karakteristik pasien hipertensi di Puskesmas Gamping I Sleman Yogyakarta. Yogyakarta.

Herwati \& Sartika, W., 2014. Terkontrolnya Tekanan Darah Penderita Hipertensi Berdasarkan Pola Diet dan Kebiasaan Oleh Raga di Padang Tahun 2011. Jurnal Kesehatan Masyarakat, Volume 8(Nomor 1), pp. 8-11.

Kishore, J., Gupta, N., Kohli, C. \& Kumar, N., 2016. Prevalence of Hypertension and Determination od Its Risk Factors in Rural Delhi. International Journal of Hypertension, 2016(ID 7962595), pp. 1 - 7.

Mills, K. T. et al., 2016. Global Disparitas of hypertension Prevalence and Control; A Systematic Analysis of Populastion- Based Studies from 90 Countries. Circulation, 134(doi: 10.1161), pp. 441-450. 
Noor, J. D. S. M., 2013. Metodologi Penelitian. Jakarta: Kencana Prenada Media Group.

Nugraha, Bayu, 2013. Hubungan Tingkat Pengetahuan Keluarga Dengan Sikap Pencegahan Komplikasi Pada Pasien Hipertensi Di Wilayah Kerja Puskesmas Sangkrah Surakarta. Surakarta.

Pangestu, Ari Asep, 2016. Efektifitas Rebusan Buah Pepaya Mengkal dan Buah Mahkota Dewa Terhadap Perubahan Tekanan Darah Tinggi pada HIpertensi di Wilayah Kerja Puskesmas Kedungbanteng. Purwokerto.

Pos, S., 2016. Sumut Pos. [Online] Available at: http://sumutpos.co/2016/11/15/pe nderita-hipertensi-di-sumutmencapai-50-ribu-lebih/ [Accessed 22 Desember 2017].

Prasetyorini, prawesti. 2012. Stres pada penyakit terhadap kejadian komplikasi hipertensi pada pasien hipertensi. Jurnal stikes volume 5, no. 1, juli 2012.

Putra, A. M. P. \& Ulfah, A., 2016. Analisis faktor Risiko Hipertensi di Puskesmas Kelayan Timur Kota Banjarmasin. Jurnal Ilmiah Ibnu Sina, Volume 1(Nomor 2), pp. 256 - 264.

Republik Indonesia, K. k., 2014. Data Propinsi Sumatera Utara Riset Kesehatan Dasar Balitbangkes, Jakarta: Kementerian Kesehatan Republik Indonesia.
Riyanto, A., 2010. Basic Data Analysis for Helath Research Training. Pengolahan dan Analisis data Kesehatan.. Medan: Sekolah Tinggi Ilmu Kesehatan Rumah Sakit Haji Medan.

Simbolon, C. A., 2016. Prevalensi penderita Hipertensi pada Lansia di Kabupaten Karo Tahun 2016. Tesis, Medan: Universitas SUmatera Utara, Fakultas Kesehatan Masyarakat.

WHO, 2013. A Global Brief Hypertension, Switzerland: Wc Health Organization 